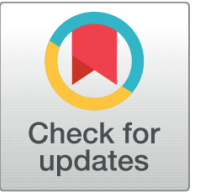

G OPEN ACCESS

Received: 23.08.2021

Accepted: 20.12.2021

Published: 09.02.2022

Citation: Chavez R (2022) Unit Heads Amidst COVID 19 Pandemic: Work-Life Balance, Talent Management Skills and Institutional Performance. Indian Journal of Science and Technology 15(5): 191-198. https://doi.org/ 10.17485/IJST/v15i5.1568

* Corresponding author.

vpaf@nipsc.edu.ph

Funding: Article processing charge is partially deferred by Indian Society for Education and Environment

Competing Interests: None

Copyright: (c) 2022 Chavez. This is an open access article distributed under the terms of the Creative Commons Attribution License, which permits unrestricted use, distribution, and reproduction in any medium, provided the original author and source are credited.

Published By Indian Society for Education and Environment (iSee)

ISSN

Print: 0974-6846

Electronic: 0974-5645

\section{Unit Heads Amidst COVID 19 Pandemic: Work-Life Balance, Talent Management Skills and Institutional Performance}

\author{
Raffy Chavez ${ }^{1 *}$ \\ 1 Vice President, Administration, and Finance, Northern Iloilo Polytechnic State College - \\ Estancia, Iloilo, Philippine
}

\section{Abstract}

Purpose: The study aims to determine the level of work-life balance, talent management skills, and institutional performance of Northern Iloilo Polytechnic State College (NIPSC) key officials during the COVID 19 pandemic. Methods: This study is descriptive-correlational research using purposive samplings. The 97 key officials from the 7 campuses were selected as respondents of this study. The researcher adopted a questionnaire focused on work balance, talent management skills, and institutional performance. To analyze the data, statistical tools like frequency count, percentage, mean, standard deviation for descriptive, and for inferential were t-test, one-way analysis of variance, and Pearson's $r$ was utilized. Results: The results revealed that the work-life balance of different units' heads was "Highly Balanced". While the talent management skills were "Highly Managed". And, the level of key officials' institutional performance was "Outstanding." Furthermore, the findings also indicate that there are no significant differences in the level of work-life balance, talent management skills, and institutional performance of school officials. The school key officials' highly balanced lifestyle was able them to cater to the needs of their work and personal life in this catastrophe. Their experiences as key officials improved their management skills and impacted and influenced them to cope with the crisis. Novelty: Higher Education Institutions (HEls) unit heads should know work-life balance for teachers and management skills to inspire colleagues for institutional performance in this virus crisis. This pandemic teaches key officials to become dynamic and visionary to manage the new educational policies by implementing different modalities and training for teachers. The four mandates such as instruction, research, extension services, and production of the college are prospering despite health protocols restrictions.

Keywords: Northern Iloilo Polytechnic State College; key Officials; Pandemic; WorkLife Balance; Management Skills; Institutional Performance 1

Introduction 


\section{Introduction}

COVID-19 has become a global health crisis with almost 36 million people having been infected and millions have died as of October 6, 2020, and counting. The outbreak of the virus in 2019 was a major problem in colleges and universities. In the US, legislators take an active role to address the challenges by introducing bills like pause collection of payments, requiring higher education institutions (HEIs) to develop emergency plans, and exploring strategies to address funding for public higher institutions ${ }^{(1)}$. Arab universities have already adopted technology and a digital environment long before the COVID19 pandemic hit the world. But the Palestine universities should address the lack of a strategic plan, digital inequity, and technology infrastructure must be given importance by creating instructional designers and evaluation processes ${ }^{(2)}$.

To lessen the spread of COVID-19, educational institutions temporarily shut down, and over 28 million Filipino learners across academic levels ${ }^{(3)}$ are forced to use blended learning ${ }^{(4)}$ or flexible learning. Coronavirus affects the education system, schools around the world shifted to distance learning just to continue the education system. But in developing countries, the lack of gadgets and connectivity hinders the new policy to prosper but designs and innovations like modular approaches, zero free internet materials, and broadcast teaching were adopted ${ }^{(5)}$. State Universities and Colleges (SUCs) in the country serve as a beacon of hope in times of pandemic. The contributions of researchers and experts in various fields were remarkable such as the Philippines-National Institutes of Health (UP-NIH) COVID-19 diagnostic kit, other institutions created face masks, face shields from recycled materials, and also protective suits ${ }^{(6)}$. Also, nineteen schools in the country were used as quarantine facilities with the collaboration of local government units (LGU) to grapple with the recent situation. With proper health protocol imposed by the Inter-Agency Task Force for the Management of Emerging Infectious Diseases (IATF-EID). The concerned agencies signed a memorandum of agreement to set up government facilities that could temporarily serve as community isolation units or quarantine facilities ${ }^{(7)}$.

Just like other countries, SUCs in the Philippines during COVID 19 also moved to alternative learning modes and technologies for delivering education serve as best practices in Southeast Asia despite the gaps and challenges ${ }^{(8)}$. The current issues, problems, and trends bought about by the pandemic in the education systems encourage experts to plan and implement based on new normal educational policy ${ }^{(9)}$. And school key officials are instruments to have effective and highly managed institutions during this pandemic. For almost 16 months with no face-to-face, together with the members of the academe, they look for solutions to implement the new normal educational policies using different modalities. Thus, this study was formulated.

In this study, unit heads are referred to key officials of the college such as college presidents, vice presidents, administrators, deans, and directors. They are the ones who plan activities, projects, and programs related to COVID 19 pandemic response. The closure of schools and shift into flexible learning is big issues and problems among key officials as the pressure to implement effectively depends on their shoulder. Hence, the work-life balance, talent management skills, and institutional performance of the unit heads of NIPSC were studied during the COVID-19 pandemic.

The important role of the teachers in learning is unquestionable. Teachers have a lot of influence on their classroom practices. Teachers should have and apply specific abilities without which their influence may not be reflected in their students' performance in the subject. For students to be able to make the connection between what is taught in school and its application in problem-solving in real life, the teacher has to be effective in their teaching. There has been no consensus on the importance of specific teacher factors, leading to the common conclusion that the existing empirical evidence does not find a strong role for teachers in the determination of academic achievement. This study, therefore, sought to investigate the influence of teacher characteristics in influencing students' performance ${ }^{(10)}$. The availability of qualified teachers determined the performance of students in schools. Further, teachers' attitudes contributed significantly to student attention in classrooms ${ }^{(11)}$. The policy shifts due to the pandemic factors like age and experiences make it difficult for teachers to adapt from face-to-face educational activities to online learning ${ }^{(12)}$.

The school faces a lot of pressure in the competence for a talented workforce, for constantly improving the teaching methods, entrants of advanced technology, and for the teachers who are inclined to achieve work-life balance specifically in this pandemic. The success of any organization depends upon the quality of the workforce, but to maintain the quality of the workforce, many schools come across several obstacles. The ability to effectively manage top talents in the organization is therefore central to employee performance and seems to form a strong association with employee commitment. As school administrators struggle to find a talented pool, they are equally faced with the dilemma of how to retain knowledgeable workers and replace the aging workforce who will be retiring ${ }^{(13)}$.

All this adds to the stress among teachers leading to imbalanced work-life equations. Thus, there is a need to study work-life balance issues vis-à-vis, teachers. A study on work-life balance initiatives and how these initiatives impact employees' personal and professional performance. It also investigates the relationship between work-life balance initiatives and employees' attitudes towards work-life conflicts. The relationship of various facets of work-family balance with organization commitment (OC) and its different dimensions among employees in the service sector. Business practices and academic research allows work- 
life balance as important factors. Furthermore, work-life balance is the top priority in many consciousness's of employers and employees $^{(14)}$. To avoid the rapid spread of the virus, many companies suggested working at home but experts included it only made that worse for maintaining a healthy work-life balance ${ }^{(15)}$. However, COVID 19 has also a positive side by revealing that many companies prioritize their employees' well-being by offering more openness to flexibility and benefits ${ }^{(16)}$.

During this pandemic, work-life balance among employed adults coupled with stress is a struggle. Assistant Professor Hoda Vaziri of the University of North Texas (UNT) together with the team developed best practices for organizations to adopt. This serves employees and increases job satisfaction and work-life balance in this pandemic ${ }^{(17)}$.

These best practices are;

1. Develop policies and practices to help employees manage work and family effectively

2. Train managers on the importance of compassion during societal crisis events

3. Recognize and reward compassionate supervisor behaviors

4. Proactively adopt new technologies that support remote work in general and in times of societal crisis.

5. Provide support services and training to employees on new technologies

6. Train employees on various coping mechanisms, such as emotion versus problem-focused, and appropriate situations in which to use them [18].

6. Train employees on various coping mechanisms, such as emotion versus problem-focused, and appropriate situations in which to use them ${ }^{(18)}$.

Talent management competencies are a set of behavioral patterns that the line managers need to attract, select, engage, develop and retain talented employees to reach specific desirable business objectives for the organization.

The organizations which continuously support talent management focus on building organizational abilities by bringing talents into the processes and systems and they focus on the development of a high level of awareness and the abilities to support talent management in three groups: the individuals themselves, the line managers, and the professionals in human resources $^{(19)}$.

Talent management is becoming one of the main tools of business competitiveness, and organizations can hardly compete without highly skilled workers and the continual investment in the human capital and to have the right people in the right places and at the right time is critical for any organization to achieve the competitive advantage. Furthermore, the success of any organization depends strongly on having talented individuals. Therefore, the ability to deal with talent and talent management TM effectively has been and will be one of the biggest challenges facing organizations today ${ }^{(20)}$. On the other hand, HRM is more focused on the development of people. Talent management is viewed as a strategic process mandatory for the global strategy ${ }^{(21)}$.

Human resources management focuses on all employees, while talent management focuses on "key employees" or "talent" or "top talent", top talent can be defined as a person "who routinely exceeds expectations while exhibiting the right behaviors and is agile in the learning approach. These are the people whom customers pay a premium and others strive to work with ${ }^{(22)}$.

The concept of integrated talent management integrates the business strategy, the human resources strategy, talent management processes, and the organizational culture ${ }^{(23)}$.

Economic shock, global health crisis, social behavior, and business impact are among the adverse consequence brought about by the COVID-19 pandemic. Also, operations of the business which includes the academe required talent management for a smooth transition in new normal policies ${ }^{(24)}$.

Institutional performance can be assessed and measured on three different levels. As one of the most complicated areas but vital for the implementation of public policy in various government sectors but one of the key fields in research ${ }^{(25)}$. In higher education, leaders and experts or key officials focus on four aspects such as teaching, research, impact, industry collaboration, and international Outlook ${ }^{(26)}$.

Today, improving institutional performance is different from decades ago. For instance, society viewed higher education as an individual benefit and expenses must be shoulder by individuals rather than by the government. Also, competition among schools to provide quality education for all is very strong especially in for-profit institutions ${ }^{(27)}$.

The study of 107 SUCs on digital governance and institutional performance results showed early and middle stages of implementation and mostly concentrated on content and usability features. Both digital governance and institutional performance have a substantial relationship. Many of these SUCs according to their levels focused on instruction, research, extension, and productions as their pillars ${ }^{(28)}$.

With the lack of knowledge in technologies and gadgets, much higher education faculty experience difficulties in the new educational policy in this pandemic. Thus, the majority disagreed with "Classroom teaching could be completely replaced by online teaching mode" ${ }^{29)}$. 
In Indian, online learning is getting popular as one of the in-demand teaching strategies in times like this; however, health issues among teachers and students are the major concern coupled with lack of connectivity. But face-to-face learning is now prohibited, the education community has no choice but to accept the current trends but with proper precautions ${ }^{(30)}$.

In the Philippines, the Commission on Higher Education (CHED) under the Unified Students Financial Assistance System for Tertiary Education (UniFAST) legislated by the House of Congress provides tertiary education subsidies (TES) to help students belong to low-income families. During this pandemic, CHED continues to release funds for SUCs and local universities and colleges (LUCs) for the academic year 2019-2020 (31).

To this effect, the main objective of the study is to identify school key officials' work-life balance, talent management skills, and institutional performance of Northern Iloilo Polytechnic State College (NIPSC) during the COVID 19 pandemic.

\section{Methods}

This is a descriptive correlational study that used purposive sampling techniques by selecting the current administrators as respondents. The instrument used to gather the data pertinent to the investigation consisted of four parts: Part One was used to obtain data about the personal factors of the respondents; Part Two, was used to determine the level school work-life balance of the respondents; Part Three, was used for talent management skills; and Part Four, was used for performance.

To measure the participants' work-life balance, the researcher used the work-life balance questionnaire by Beluso. The worklife balance questionnaire is composed of sixty-one (61) statements that pertain to respondents' work-life balance activities in different indicators such as personal factors; work-related factors; and non-work-related factors.

To measure the participants' talent management skills, the researcher used the talent management skills questionnaire ${ }^{(32)}$. The talent questionnaire was composed of forty-three (43) statements that pertain to respondents' work talent management skills. The items indicate the degree of the respondents' agreement or disagreement with the responses with the following descriptions and numerical weights; 5 - strongly agree; 4 - agree; 3 - neither agree nor disagree; 2 - disagree; 1 - strongly disagree. The reliability coefficient (Cronbach alpha) in the pilot study, for all 15 items will be 0.83 .

The data gathered were subjected to computer-processed statistics employing the Statistical Package for the Social Sciences Software (SPSS) using frequency count, percentage, mean, standard deviation, t-test, One-Way Analysis of Variance, and Pearson's $r$. The margin of error was set at .05 .

\section{Results and Discussion}

Table 1 shows the level of key officials' work-life balance during the pandemic.

Table 1. Level of Key Officials' Work-Life Balance

\begin{tabular}{llll}
\hline Work-Life Balance & Mean & Verbal Description & SD \\
\hline Personal Life Factor & 4.49 & Highly Balanced & .525 \\
Work Related Factor & 4.38 & Highly Balanced & .510 \\
General Mean & 4.44 & Highly Balanced & .512 \\
\hline
\end{tabular}

Legend: 4.21-5.00 (Highly Balance);3.41-4.20 (Moderately Balanced);

2.61-3.40 (Balanced); 1.81-2.60 (Moderately Imbalanced); 1.00-1.80

(Imbalanced).

The results reveal the level of school administrators' work-life balance. It was classified according to Personal Life Factor $(\mathrm{M}=4.49, \mathrm{SD}=.525)$ and Work-Related Factor $(\mathrm{M}=4.38, \mathrm{SD}=.510)$. Both categories had a description of "Highly Balanced" with Personal Factor taking the highest mean.

Table 2 shows the level of school administrators' talent management skills when categorized into: "Establishes and maintains

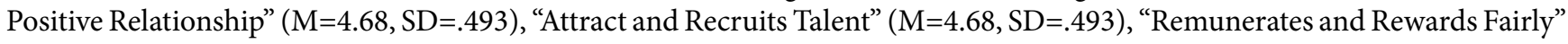
$(\mathrm{M}=4.50, \mathrm{SD}=.503)$, "Provides Meaningful and Challenging Work" $(\mathrm{M}=4.50, \mathrm{SD}=.503)$, "Identifies and Differentiates Talented Employees" ( $\mathrm{M}=4.50, \mathrm{SD}=.503)$, "Develops Others" $(\mathrm{M}=4.38, \mathrm{SD}=.510)$, and "Display a Talent Management Mindset" (M=4.38, $\mathrm{SD}=.510)$. All categories had a description of "Highly Managed" with "Establishes and maintains Positive Relationship" and "Attract and Recruits Talent" as the highest mean scores.

One of the major issues of organizations on the Covid-19 pandemic is about impairing the capacities of workers. This unexpected event challenges the skills and knowledge of high-ranking officials ${ }^{(33)}$. The lockdown causes a sudden shift to work from home scheme. The availability of technology and connectivity is the top priority. Thus, the key officials should revisit the policy and make revisions for the new normal ${ }^{(34)}$. The study on work-life balance showed health is important as a 
family ${ }^{(35)}$. Work from home policy is a fruitful innovation to both employees and organizations ${ }^{(36) .}$

Table 2 shows the talent management skills of key officials of NIPSC during Covid 19 crisis.

Table 2. Talent management skills of key officials during Covid 19 crisis

\begin{tabular}{llll}
\hline Talent Management Skills & Mean & Mean & SD \\
\hline Establishes and Maintains Positive Relationship & 4.68 & Highly Managed & .493 \\
Attract and Recruits Talent & 4.68 & Highly Managed & .493 \\
Remunerates and Rewards Fairly & 4.50 & Highly Managed & .503 \\
Provides Meaningful and Challenging Work & 4.50 & Highly Managed & .503 \\
Identifies and Differentiates Talented Employees & 4.50 & Highly Managed & .503 \\
Develops Others & 4.38 & Highly Managed & .510 \\
Display a Talent Management Mindset & 4.38 & Highly Managed & .510 \\
\hline General Mean & $\mathbf{4 . 5 2}$ & Highly Managed & $\mathbf{. 5 1 9}$ \\
\hline
\end{tabular}

Legend: 4.21-5.00 (Highly Managed); 3.41-4.20 (Moderately Managed); 2.61-3.40 (Managed); 1.812.60 (Moderately Unmanaged); 1.00-1.80 (Unmanaged).

Table 3 show also reveals the level of school administrators' institutional performance. This level of performance was categorized into Extension $(\mathrm{M}=4.68, \mathrm{SD}=.493)$, Production $(\mathrm{M}=4.5=, \mathrm{SD}=.503)$, Instruction $(\mathrm{M}=4.49, \mathrm{SD}=.525)$, and Research $(\mathrm{M}=4.38, \mathrm{SD}=.510)$ where all Performance indicators had a description of "Outstanding" with Extension having the highest mean.

Redesigning talent management practices during this pandemic is important. Remote working is the new normal ${ }^{(37) .}$

Table 3. Level of Key Officials' Institutional Performance

\begin{tabular}{llll}
\hline Performance & Mean & Description & Std. Deviation \\
\hline Extension & 4.68 & Outstanding & .493 \\
Production & 4.50 & Outstanding & .503 \\
Instruction & 4.49 & Outstanding & .525 \\
Research & 4.38 & Outstanding & .510 \\
\hline General Mean & $\mathbf{4 . 5 1}$ & Outstanding & $\mathbf{. 5 0 1}$ \\
\hline
\end{tabular}

Legend: 4.21-5.00 (Outstanding); 3.41-4.20 (Very Good); 2.61-3.40 (Good); 1.81-2.60 (Fair); 1.00-1.80 (Needs Improvement).

The results also revealed that there are no significant differences in the level of work life balance of school administrators when classified according to Educational Attainment (Personal Life Factor: $\mathrm{F}(2,87)=.071, \mathrm{p}=.931$; Work Life Factor: $\mathrm{F}(2,87)$ $=.214, \mathrm{p}=.808$ ) and Academic Rank (Personal Life Factor: $\mathrm{F}(3,86)=.066, \mathrm{p}=.978$; Work Life Factor: $\mathrm{F}(3,86)=.128, \mathrm{p}=.944)$.

Also, there were no significant differences in the level of talent management of school administrators when classified to age (Display a Talent Management Mindset: $\mathrm{t}(88)=.385, \mathrm{p}=.701$; Attract and Recruit Talent: $\mathrm{t}(88)=.399, \mathrm{p}=.691$; Identify and Differentiates Talented Employees: $\mathrm{t}(88)=.000, \mathrm{p}=1.000$; Develops Others: $\mathrm{t}(88)=.385, \mathrm{p}=.701$; Establish and Maintains Positive Relationship: $\mathrm{t}(88)=.399, \mathrm{p}=.691$; and Provides Meaningful and Challenging Work: $\mathrm{t}(88)=.000, \mathrm{p}=1.000)$.

In addition, the findings indicates that there were no significant differences in the level of talent management of school administrators when classified to gender (Display a Talent Management Mindset: $\mathrm{t}(88)=.430, \mathrm{p}=.668$; Attract and Recruit Talent: $\mathrm{t}(88)=.671, \mathrm{p}=.504$; Identify and Differentiates Talented Employees: $\mathrm{t}(88)=.627, \mathrm{p}=.532$; Develops Others: $\mathrm{t}(88)$ $=.430, \mathrm{p}=.668$; Establish and Maintains Positive Relationship: $\mathrm{t}(88)=.671, \mathrm{p}=.504$; Provides Meaningful and Challenging Work: $\mathrm{t}(88)=.627, \mathrm{p}=.532$; and Remunerates and Rewards Fairly: $\mathrm{t}(88)=.627, \mathrm{p}=.532$ )

Further, the outcomes exposed that there were no significant differences in the level of talent management of school administrators when classified to the length of

(Display a Talent Management Mindset: $\mathrm{t}(88)=-.304, \mathrm{p}=.762$; Attract and Recruit Talent: $\mathrm{t}(88)=-.316, \mathrm{p}=.753 ; \mathrm{Identify}$ and Differentiates Talented Employees: $\mathrm{t}(88)=.000, \mathrm{p}=1.000$; Develops Others: $\mathrm{t}(88)=-.304, \mathrm{p}=.762$; Establish and Maintains Positive Relationship: $\mathrm{t}(88)=-.316, \mathrm{p}=.753$; and Provides Meaningful and Challenging Work: $\mathrm{t}(88)=.000, \mathrm{p}=1.000$; and Remunerates and Rewards Fairly: $\mathrm{t}(88)=.000, \mathrm{p}=1.000)$.

Additionally, there were no significant differences in the level of talent management of school administrators when classified to educational attainment of (Display a Talent Management Mindset: $\mathrm{F}(2,87)=.214, \mathrm{p}=.808$; Attract and Recruit Talent: $\mathrm{F}(2,87$ ) $=.068, \mathrm{p}=.934$; Identify and Differentiates Talented Employees: $\mathrm{F}(2,87)=.255, \mathrm{p}=.775$; Develops Others: $\mathrm{F}(2,87)=$ 
$.214, \mathrm{p}=.808$; Establish and Maintains Positive Relationship: $\mathrm{F}(2,87)=.068, \mathrm{p}=.934$; Provides Meaningful and Challenging Work: $\mathrm{F}(2,87)=.255, \mathrm{p}=.775$; and Remunerates and Rewards Fairly: $\mathrm{F}(2,87)=.255, \mathrm{p}=.775)$.

Moreover, it revealed that there were no significant differences in the level of talent management of school administrators when classified to the educational attainment of

(Display a Talent Management Mindset: F $(3,86)=.128, \mathrm{p}=.994$; Attract and Recruit Talent: $\mathrm{F}(3,86)=.055, \mathrm{p}=.983$; Identify and Differentiates Talented Employees: $F(3,86)=1.409, \mathrm{p}=.246$; Develops Others: $\mathrm{F}(3,86)=.128, \mathrm{p}=.944$; Establish and Maintains Positive Relationship: $\mathrm{F}(3,86)=.055, \mathrm{p}=.983$; Provides Meaningful and Challenging Work: $\mathrm{F}(3,86)=1.409, \mathrm{p}=$ .246 ; and Remunerates and Rewards Fairly: F $(3,86)=1.409$, $\mathrm{p}=.246)$.

Likewise, it revealed that there were no significant differences in the level of institutional performance of school administrators when grouped according to age (Instruction: $\mathrm{t}(88)=.815, \mathrm{p}=.369$; Research: $\mathrm{t}(88)=.039, \mathrm{p}=.845$; Extension: $\mathrm{t}(88)=.908, \mathrm{p}=.343$; and Production: $\mathrm{t}(88)=.346, \mathrm{p}=.758)$. And, there were no significant differences in the level of institutional performance of school administrators when grouped according to sex (Instruction: $\mathrm{t}(88)=.328, \mathrm{p}=.369$; Research: $\mathrm{t}(88)=.831, \mathrm{p}=.845$; Extension: $\mathrm{t}(88)=.155, \mathrm{p}=.343$; and Production: $\mathrm{t}(88)=.000, \mathrm{p}=.701)$.

There were no significant differences in the level of institutional performance of school administrators when grouped according to length of service (Instruction: $\mathrm{t}(88)=.479, \mathrm{p}=.328$; Research: $\mathrm{t}(88)=.872, \mathrm{p}=.831$; Extension: $\mathrm{t}(88)=.451, \mathrm{p}=$ .155 ; and Production: $\mathrm{t}(88)=.529, \mathrm{p}=1.000)$. Also, the results uncovered that there were no significant differences in the level of institutional performance of school administrators when grouped according to educational attainment (Instruction: $\mathrm{F}(2,87)=$ $.071, \mathrm{p}=.931$; Research: $\mathrm{F}(2,87)=.214, \mathrm{p}=.808$; Extension: $\mathrm{F}(2,87)=.068, \mathrm{p}=.934$; and Production: $\mathrm{F}(2,87)=.255, \mathrm{p}=$ .775. It was also discovered that there were no significant differences in the level of institutional performance of school administrators when grouped according to academic rank (Instruction: $\mathrm{F}(3,86)=.066, \mathrm{p}=.978$; Research: $\mathrm{F}(3,86)=.128, \mathrm{p}=$ .944; Extension: $\mathrm{F}(3,86)=.055, \mathrm{p}=.983$; and Production: $\mathrm{F}(3,86)=1.246, \mathrm{p}=.246$.

The results further showed that there is a strong significant relationship between work-life balance and institutional performance $(\mathrm{r}=1.000, \mathrm{p}=.000)$. And, there is a strong significant relationship between work-life balance and institutional performance $(\mathrm{r}=.436, \mathrm{p}=.000)$.

Nowadays, teachers are facing a lot of stress and a low level of work-life balance; thus, interventions like mental health awareness are important ${ }^{(38)}$. F urthermore, teachers with the same age bracket have similar perceptions in terms of personal life interference and work-life enhancement ${ }^{(39)}$.

In the business world, talent management is a source of competitiveness to attract employees to perform better for the success of the companies. Thus, leaders in these companies worked hard as innovative assets to sustain potentials, talented employees. However, this skill must be reviewed and often assessed ${ }^{(40)}$. Managing a group of people; specifically, in academe requires great talent. Talent management skills showed a great impact on the performance of the organization. If this skill is properly managed and implemented it can help the organization achieve goals and vision ${ }^{(41)}$. In higher education, $t$ talent management strategies of a private higher education institution are still a work in progress due to lacking evidence ${ }^{(42)}$.

Article XIV Section 10 of the 1987 Philippines Constitutions state to give priority to research. Furthermore, the Education Act of 1994 or Republic Act No. 7722 created the CHED and one of the mandated is the research ${ }^{(43)}$. Research is the heart of every SUCs in the country. Through research, we can improve instruction, create extensions and produce production. However, many higher institutions in the archipelago have little interest in research. One of them is NIPSC and but the administration works hard to encourage faculty to engage in research by giving funding and sending to various conferences local and international.

Higher education institutions (HEIs) comprising the Philippine Association of State Universities and Colleges (PASUC) highlight the role of extension and research this pandemic during their annual summit last August 26, 2020. During this meeting participated by 112 member organizations shared research and extension activities to combat COVID 19 pandemic ${ }^{(44)}$. All higher institutions are a force to engage in COVID 19 related types of research.

\section{Conclusions}

The highly balanced lifestyle of the key officials enabled them to cater to the need of their work and personal life during the COVID-19 pandemic. These attitudes and behaviors of NIPSC unit heads are a big help to the ideal norms that are affected by the new normal educational policy due to the current situations. Work-life balance for administrators was supervisor-driven; administrators who worked in different divisions and different areas within those divisions had varied work-life experiences. Therefore, it was concluded that the school administrators highly manage the talents of their constituents which resulted in a good relationship in the state college. There was a need to consider the work-life balance of the administrators to improve the institutional performance of the campuses despite limited access because of various restrictions to combat the rapid spread of the coronavirus. A policy must be formulated as best practices of NIPSC to battle against any human and natural disasters in the future to safeguard the quality education to various clientele. 


\section{References}

1) Higher Education Responses to Coronavirus (COVID-19). National Conference of State Legislatures. 2021. Available from: https://www.ncsl.org/research/ education/higher-education-responses-to-coronavirus-covid-19.aspx.

2) MUKH YA, SALHAB R. The digital transformation challenges in higher education institution in Palestine during the Covid-19 crisis. International Journal of Humanities and Educational Research. 2021;03(04):95-100. Available from: https://dx.doi.org/10.47832/2757-5403.4-3.8. doi:10.47832/27575403.4-3.8.

3) Joaquin JJB, Biana HT, Dacela MA. The Philippine Higher Education Sector in the Time of COVID-19. Frontiers in Education. 2020;5. Available from: https://dx.doi.org/10.3389/feduc.2020.576371.

4) Tupas FP, Linas-Laguda M. Blended Learning - An Approach in Philippine Basic Education Curriculum in New Normal: A Review of Current Literature. Universal Journal of Educational Research. 2020;8(11):5505-5512. Available from: https://dx.doi.org/10.13189/ujer.2020.081154.

5) Tadesse S, Muluye W. The Impact of COVID-19 Pandemic on Education System in Developing Countries: A Review. Open Journal of Social Sciences. 2020;08(10):159-170. Available from: https://dx.doi.org/10.4236/jss.2020.810011.

6) PH Universities and Colleges in Action to Combat COVID-19.. Available from: https://news.ipophil.gov.ph/news/ph-universities-and-colleges-inactionto-combat-covid-19/.

7) State universities and colleges continue the COVID-19 fight with quarantine facilities. . Available from: https://pia4b.wordpress.com/2020/08/22/stateuniversities-and-colleges-continue-COVID-19-fight-with-quarantine-facilities.

8) Tria JZ. The COVID-19 Pandemic through the Lens of Education in the Philippines: The New Normal. International Journal of Pedagogical Development and Lifelong Learning. 2020;1(1):ep2001-ep2001. Available from: https://doi.org/10.30935/ijpdll/8311.

9) Tupas FP, Matsuura T. Moving Forward in STEM Education, Challenges and Innovations in Senior High School in the Philippines: The Case of Northern Iloilo Polytechnic State College. Jurnal Pendidikan IPA Indonesia. 2019;8(3):407-416. doi:10.15294/jpii.v8i3.19707.

10) Akinsolu AO. Teachers and students' academic performance in Nigerian secondary schools: Implications for planning Florida. Journal of Educational Administration \& Policy. 2010;3(2):86-103.

11) Alhawsawi S, Jawhar SS. Negotiating pedagogical positions in higher education during COVID-19 pandemic: teacher's narratives. Heliyon. 2021;7(6):e07158-e07158. Available from: https://dx.doi.org/10.1016/j.heliyon.2021.e07158.

12) The influence of teachers' characteristics on students' academic performance in secondary schools. . Available from: https://projectsng.blogspot.com/ 2019/06/theinfluence-of-teachers- 6 .html.

13) Strategic human resource management: gaining a competitive advantage. . Available from: https://dokumen.pub/strategic-human-resourcesmanagement-gaining-a-competitive-advantages-2nd-canadian-edition.

14) Morgan H, Jardin D, = HO. HR + OD = Integrated Talent Management. OD Practitioner. 2010;42(4):23-29.

15) Work-life balance suffers under COVID-19 pandemic: expert. . Available from: https://www.citynews1130.com/2021/03/work-life-balance-suffersunder-pandemic.

16) COVID-19 has been both good and bad for work-life balance. . Available from: https://peoplematters.in//article/compensation-benefits/covid-19-hasbeen-both-good-and-bad-for-work-life-balance-26159?media_type=article\&subcat=employee-relations\&title=covid-19-has-been- both-good- andbad-for-work-life-balance\&id=26159.

17) Offering 'best practices for work-life balance during a pandemic. . . Available from: https://research.unt.edu/news/offering-'best-practices'-for-worklife-balance-during-pandemic.

18) Tahav A, Sirková M. Zborníkvedeckýchpráckatedryekonómie a ekonomiky ANNO. Prešov: FakultamanažmentuPrešovskejuniverzity v Prešove. 2012;p. $15-24$.

19) Talent Edge 2020: Blueprints for the new normal. 2020. Available from: http://www.Deloitte.com/us/talent.

20) Vladescu A. The possibility of implementing talent management in the public sector. Management \& Marketing. 2012;7(2):351-362.

21) Morgan H, Jardin D. HR+OD=Integrated talent. OD Practitioner. 2010;42(4):23-29.

22) Silzer D, Dowell B. Strategy-driven talent management. A leadership imperative. San Francisco. John Wiley \& Sons. 2010.

23) Azizi MR, Atlasi R, Ziapour A, Abbas J, Naemi R. Innovative human resource management strategies during the COVID-19 pandemic: A systematic narrative review approach. Heliyon. 2021;7(6):e07233-e07233. Available from: https://dx.doi.org/10.1016/j.heliyon.2021.e07233.

24) Araby M, Ayaad N. The dilemma of institutional performance assessment in the governmental sector: A proposed KPIs model. Journal of Humanities and Applied Social Sciences. 2020;2(2).

25) Institutional Performance. . Available from: https://www.timehighereducation.com/hub/consultancy/p/institutiona;performace.

26) Institutional Portfolio Management: A Framework to Improve Institutional Performance. . Available from: https://er.educause/articles/2016/5/5/ institutional-portfolio-management-a-framework-to-improve-institutional-performance.

27) Chua C. Governance Implementation and Institutional Performance of State Universities and Colleges (SUCs) in the Philippines. Journal of Computer Engineering and Intelligent Systems. 2014;5(2).

28 ) and JPLA. A study on faculty perspective towards alternative teaching practices (E-Learning - Blackboard) during COVID 19. Indian Journal of Science and Technology. 2020;13(34):3538-3548. Available from: https://dx.doi.org/10.17485/ijst/v13i34.1205.

29) Tyagi H, Malik S. Online teaching in Delhi-NCR schools in India during Covid-19 pandemic. Indian Journal of Science and Technology. 2020;13(38):40364054. Available from: https://doi.org/10.17485/IJST/v13i38.1613.

30) TES stipends are now available to grantees in SUCS and LUCs amid COVID 19 outbreak. . Available from: https://ched.gov.ph/up-content/uploads/PRTES-Release.pdf.

31) Oehley A, Theron C. The development and evaluation of a partial talent. Management Dynamics. 2010;19(3):2-28.

32) Mythili DP, Alban N. Stress and Work-life balance of school teachers: a social work intervention. Journal of Social Work Education and Practices. 2018;3(2):57-61.

33) Tiago FAC, Sigahi BC, Kawasaki I, Bolis, Sandra N. Morioka A systematic review on the impacts of Covid-19 on work: Contributions and a path forward from the perspectives of ergonomics and psychodynamics of work. Human Factors and Ergonomics in Manufacturing \& Service Industries. 2021;31(4):375388. Available from: https://doi.org/10.1002/hfm.20889.

34) Achieving Work-Life Balance During the Covid-19 Pandemic. 2021. Available from: https://ateneo.edu/cord/news/achieving-work-life-balance-duringcovid-19-pandemic. 
35) Gragnano A, Simbula S, Miglioretti M. Work-Life Balance: Weighing the Importance of Work-Family and Work-Health Balance. International Journal of Environmental Research and Public Health. 2020;17(3):907-907. Available from: https://dx.doi.org/10.3390/ijerph17030907.

36) Chanana N, Sangeeta. Employee engagement practices during COVID-19 lockdown. Journal of Public Affairs. 2021;21(4). Available from: https: //dx.doi.org/10.1002/pa.2508.

37) Reinventing talent management practices to drive business. 2020. Available from: https://www.indiatoday.in/education-today/jobs-and-careers/story/ covid-19-reinventing-talent-management-practices-to-drive-business- .

38) Irfam A, Ft A. Work-life balance among teachers: An empirical study. IOSR Journal of Business and Management. 2015;17:1-11.

39) Baqutayan SMS. Is Talent Management Important? An Overview of Talent Management and the Way to Optimize Employee Performance. Mediterranean Journal of Social Sciences. 2014;5(23):2290-2295. Available from: https://dx.doi.org/10.5901/mjss.2014.v5n23p2290.

40) Sareen P, Mishra S. A study of talent management and its impact on the performance of the organization. IOSR Journal of Business and Management. 2016;18(2III):66-73.

41) Rudhumbu N, Maphosa C. Implementation of Talent Management Strategies in Higher Education: Evidence from Botswana. Journal of Human Ecology. 2015;49(1-2):21-32. Available from: https://dx.doi.org/10.1080/09709274.2015.11906820.

42) Pardo CG. Institutional research capability and performance of the University of Northern Philippines. International Journal of Scientific and Engineering Research. 2018;9(10).

43) PASUC highlights SUCs role in Covid-19 response. . Available from: https://www.manilatimes.net/2020/09/03/campus-press/pasuc-highlights-sucsrole-in-covid-19-respones.

44) Pandemic highlights the importance of research. . Available from: https://businessmirror.com.ph/2021/03/14/pandmeic-highlighst-the-importance-ofresearch. 